\title{
GONSIDERATIONS IN THE REGULATION OF BIOLOGICAL RESEARCH
}

\section{INTRODUCTION}

The recent development of recombinant DNA research techniques, with the attendant possibility of genetic manipulation, has focused public attention on the dangers and benefits of biological research which carries uncertain risks. ${ }^{1}$ Much of the public discussion of DNA research has dwelt on speculative dangers which could result, ${ }^{2}$ but the research also anticipates significant societal benefits. ${ }^{3}$ The scientific community is itself divided as to the possible hazards of such research. ${ }^{4}$

While recent assessments appear to demonstrate that the potential risks of recombinant DNA research are not as great as was originally feared, ${ }^{5}$ the best that can be said is that no one knows. Both the likelihood of any accident occurring and the degree of harm should such an accident occur remain uncertain. ${ }^{6}$

Both scientists and local communities have attempted to control recombinant DNA research. ${ }^{7}$ Although Congress has not yet acted, several bills have been proposed to regulate the area. ${ }^{8}$ All of these

1 For scientific discussion of recombinant DNA research intelligible to the layman, see, e.g., Grobstein, The Recombinant DNA Debate, 237 ScrentrFIc AM., July, 1976, at 22; Miller, Recombinant DNA Research, 111 ScL. News 216 (1977); Schneider, Genetic Engineering: Threat and Promise, Teck. Rev., Oct./Nov. 1976, at -; Wade, Genetic Manipulation: Temporary Embargo Proposed on Research, 185 Scr. 332 (1974) [hereinafter cited as Wade, Embargo]; Comment, Genetic Manipulation: Research Regulation and Legal Liability Under International Law, 7 CAT. W. INT'L L.J. 203 (1977).

2 See Cohen, Recombinant DNA: Fact and Fiction, 195 Sct. 654 (1977).

3 See id.

4 See, e.g., Chargaff, On the Dangers of Genetic Meddling, 192 Scr. 938 (1976); Cohen, supra note 2; Culliton, Recombinant DNA: Cambridge City Council Votes Moratorium, 193 Sar. 300 (1976); Grobstein, supra note 1; Helling \& Allen, Freedom of Inquiry and Scientific Responsibility, 26 BroScr. 609 (1976); Hubbard, Gazing Into the Crystal Ball, 26 BroScr. 608 (1976); Miller, supra note 1; Roblin, Reflections on Issues Posed by Recombinant DNA Molecule Technology, 265 Annals N.Y. ACaD. Scr. 59 (1976); Wade, Embargo, supra note 1; Wade, Recombinant DNA: NIH Sets Strict Rules to Launch New Technology, 190 Scr. 1175 (1975); Watson, An Imaginary Monster, 33 Bull. Arom. Scr. 12 (1977).

5 See Culliton, Recombinant DNA Bills Derailed: Congress Still Trying to Pass a Law, 199 Scr. 274 (1978).

6 See sources cited in notes 1-4 supra.

7 See Wade, Gene-Splicing: At Grass-Roots Level a Hundred Flowers Bloom, 195 Scr. 558 (1977) [hereinafter cited as Wade, Grass-Roots]. See also text accompanying notes $10-29$ infra.

8 See, e.g., H.R. 11192, 95th Cong., 2d Sess. (1978) (Reps. Rogers and Staggers); S. 1217, Amend. No. 754, 95th Cong., lst Sess. (1977) (Sen. Nelson); 
attempts at control have focused solely on DNA research, without addressing why that technique presents a unique problem. Other areas of biological research, such as those dealing with pathogenic bacteria, would appear to present similar dangers.

James Watson, the original discoverer of DNA's structure, commented in the course of a meeting of scientists convened to establish guidelines for DNA research:

As someone in charge of a tumor virus laboratory, I feel we are working with something which is instinctively more dangerous than anything I have heard about here [recombinant DNA] . . . The dangers involved are probably no greater than working in a hospital. You have to live with the fact that someone may sue for $\$ 1$ million if you are careless. ${ }^{9}$

Dr. Watson was arguing against the need for any control over DNA research. It is the position of this Comment, however, that afterthe-fact tort remedies such as those he suggests are totally inadequate when the risks include widespread damage to the public health and welfare. Some form of institutionalized preventive control is essential. The same considerations which have led to the call for control over the recombinant technique apply equally well to the other hazardous biological activities mentioned.

Without delving into the scientific debate over research regulation, and without delimiting just what other activities should be brought under the "biohazard" umbrella, this Comment will explore legal issues surrounding the regulation of potentially hazardous biological research. To devise an equitable balance between the concerns of scientists and those of laymen, the drafting of federal legislation to create a representative regulatory commission with broad preemptive powers over local control will be proposed. The constitutional ramifications of regulation of scientific research will be examined, as will various administrative procedures which will take into consideration both public and scientific concerns in the proposed regulatory framework.

S. 1217, Amend. No. 1713, 95th Cong., 2d Sess. (1978) (Sen. Kennedy). Specific provisions of these bills will be discussed infra as relevant. It is highly possible that some congressional action, most likely in the House, will have taken place by the time this Comment appears in print.

0 Wade, Genetics: Conference Sets Strict Controls to Replace Moratorium, 187 Scr. 931, 933 (1975) [hereinafter cited as Wade, Conference]. 


\section{Who Should Control Biological Research?}

\section{A. Scientific Self-Regulation}

Assuming that some control over biological research is necessary, it must next be determined where responsibility for exercising that control should rest. One possible option is to leave regulatory decisionmaking to the scientific community itself. This was the initial response to the DNA question, and remains the major current solution to control of other biohazards.

The initial impetus for regulation of recombinant DNA research came in an open letter to the scientific community in Science magazine, ${ }^{10}$ calling for a worldwide moratorium on certain "high risk" experimentation until the potential hazards could be evaluated or adequate safeguards developed.11 Eight months later the letter was followed by a major international conference, organized by prominent researchers, at the Asilomar Conference Center in California; ${ }^{12}$ the Asilomar conference resulted in the lifting of the total voluntary ban, replacing it with a set of safety conditions for a variety of future experiments, along with a continued voluntary ban on research determined to be hazardous under any circumstances. ${ }^{\text {i3 }}$

The guidelines formulated at Asilomar became the basis for regulations promulgated by the National Institutes of Health (NIH) to govern federally funded research. ${ }^{14}$ These guidelines provide for both physical and biological containment requirements of increasing severity depending on the perceived level of danger. The physical guidelines ensure that no dangerous organism will escape the laboratory; the biological requirements ensure that no organism which does escape will be able to survive outside the laboratory. ${ }^{15}$

10 Committee on Recombinant DNA Molecules, Potential Biohazards of Recombinant DNA Molecules, 185 Scr. 303 (1974). Among the eleven signatories of the letter were Nobel laureates David Baltimore and James D. Watson. Simultaneously with its appearance in Science, the letter was also published in 11 Proc. Nat'i ACAD. ScI. USA 2593 (1974) and in the British science magazine, Nature, 250 NATURE 175 (1974).

11 Committee on Recombinant DNA Molecules, Potential Biohazards of Recombinant DNA Molecules, 185 Scr. 303 (1974).

12 Wade, Conference, supra note 9.

13 Id. As with the moratorium, the guidelines developed at Asilomar had only moral, and not legal, force. They were nonetheless followed by the scientific community. See, e.g., Schneider, supra note 1; Wade, Recombinant DNA: Cambridge City Council Votes Moratorium, 193 Sct. 300 (1976). For international responses, see Leeper, British Biologists Urge Adoption of Genetic Research Guidelines, 25 BroScr. 594 (1975); Leeper, World Body to Monitor Genetic Experiments, 26 BioScr. 740 (1976); No DNA Rules from WHO, 26 BroScr. 740 (1976).

1441 FED. REG. 27,911-17 (1976).

$15 I d$. 
Both scientists and the general public were consulted as NIH struggled to devise appropriate guidelines. ${ }^{16}$ A public hearing was held to review the proposed guidelines before a specially assembled committee, ${ }^{17}$ and the opinions of public interest groups were solicited as well. ${ }^{18}$ The meeting was significant because it gave nonscientists an opportunity to comment for the first time on the procedures developed by the scientific community for handling recombinant DNA. ${ }^{19}$

Even though NIH sought public participation in the formulation of its guidelines, the result remained essentially scientific selfregulation, as $\mathrm{NIH}$ itself sponsors the research. It has been suggested that the NIH regulations were motivated primarily by scientists' self-interest, ${ }^{20}$ and as such were unresponsive to wider societal concerns. ${ }^{21}$

A further problem with regulation by NIH is that their guidelines restrict only research conducted with federal funding; ${ }^{22}$ private industry, which is becoming increasingly involved in DNA research, remains unregulated..$^{23}$

16 See Roblin, supra note 4.

17 Wade, Recombinant DNA: Guidelines Debated at Public Hearing, 191 Scr. 834 (1976). Included on the panel was David Bazelon, Chief Judge of the District of Columbia Court of Appeals. Id.

18 Id.

19 Id.

20 Wade, Recombinant DNA: A Critic Questions the Right to Free Inquiry, 194 Scr. 303, 305 (1976) (biologist Robert Sinsheimer charges that as only the interests and concerns of the scientific community were involved in the promulgation of the guidelines, the interests of the rest of society were ignored).

21 Grobstein, Recombinant DNA Research: Beyond the NIH Guidelines, 194 Scr. 1133,1134 (1976).

22 Id.

23 See Wade, Grass-Roots, supra note 7. All the major pharmaceutical companies are interested in recombinant techniques, and at least six are actively engaged in DNA research, as are at least two smaller companies. Id. 559. The Pharmaceutical Manufacturers Association has been advocating voluntary compliance with the NIH guidelines, but has recently been leaning toward some form of actual regulation. Id.

One measure of the interest of drug companies in this type of research is evidenced in the fact that Miles Laboratories sponsored a symposium on "The Impact of Recombinant Molecules on Science and Society" at the Massachusetts Institute of Technology as early as the summer of 1976. Schneider, supra note 1.

A possible mode of regulating commercial research is through the patent process. The Patent and Trademark Office has begun giving accelerated processing to patent applications for gene-splicing techniques if the applicants abide by NIH regulations. However, the Patent Office allows deviation from those regulations to the extent that the NIH disclosure requirements need not be met if disclosure would prejudice foreign patent rights. This exemption has been severely criticized. Wade, Grass-roots, supra note 7.

Reliance on the patent process to control commercial research and applications of DNA technology is risky at best, because it assumes that all companies will seek patents; industrial research, as opposed to commercial applications, would remain unregulated. 
Even though scientists may be in the best position to assess the probability of certain dangers occurring, they are no better able than the layman to judge the significance of these hazards and the social costs associated with them, or to strike a balance based on difficult value choices. ${ }^{24}$ In fact, because of the high value placed by the scientific community on unrestricted research, that community is perhaps less competent to judge the position research should hold in the community at large. Because research into recombinant DNA and other equally dangerous procedures has the potential of greatly affecting society as a whole, the public, or representatives of the public, must have a voice in the extent and nature of regulation. To the extent the public has been excluded from meaningful participation in regulatory procedures, scientists are being given a monopoly over basic value and policy decisions beyond their expertise..$^{25}$

\section{B. Federal or Local Control?}

Once it has been decided that some form of governmental control over biological research is necessary, the next major issue is whether such regulation should be exclusively federal, or whether there should be some opportunity for local control.

The most publicized effort to establish local control occurred when Cambridge, Massachusetts imposed a three-month moratorium on research which would have required the highest levels of containment under the NIH regulations, and established the Cambridge Laboratory Experimentation Review Board, which held hearings on the advisability of recombinant DNA research at Harvard University and the Massachusetts Institute of Technology. ${ }^{26}$ The Board, composed of both scientists and laymen, eventually recommended

24 Green, The Risk-Benefit Calculus in Safety Determinations, 43 GEo. WASH. L. REv. 791, 799 n.31 (1975). See also Martin, The Proposed "Science Court," 75 Micr. L. Rev. 1058 (1977).

25 This conclusion is strengthened by recent NIH actions. Apparently in response to pressure from the scientific community, NIH has proposed revised, somewhat less stringent regulations for DNA research. 42 Fed. Reg. 49,596-605 (1977). The process of revision was severely criticized as not providing sufficient public participation procedures. Wade, Gene-Splicing Rules: Another Round of Debate, 199 Scx. 30 (1978).

26 Culliton, supra note 4; Wade, Gene-Splicing: Cambridge Citizens OK Research but Want More Safety, 195 Scr. 268 (1977). The moratorium was in "good faith" and not enforceable, as the Cambridge City Council lacked authority to decree a binding ban: the health commissioner had the power to ban the research by declaring it illegal, but, at the time of the moratorium, this position was vacant. Culliton, supra note 4. 
guidelines, passed into law by the City Council early in 1977,27 which were slightly more restrictive than those established by $\mathrm{NIH}^{28}$

Although the Cambridge response ${ }^{28}$ to the problem of uncontrolled scientific experimentation within its borders was a useful and legitimate one, local control is not the most appropriate long-term solution. There are compelling reasons for the federal government to totally preempt this field.

A major problem with local control is that other localities may not be as "enlightened" as Cambridge. ${ }^{30}$ They may not, for example, give sufficient deference to the need for scientific advice before regulatory action is undertaken, but may instead respond to popularized scare tactics and uninformed public hysteria. Decisionmaking may become entirely politicized. Even assuming access to scientific information is available, states may differ in their "readiness to accept new developments, particularly when these developments involve scientific matters that have a direct impact on social and even religious commitments." 31 It is also questionable whether a system of piecemeal regulation would be effective at protecting the public, for microbes fleeing from a low-safeguard locality are unlikely to recognize the political boundary of an adjacent high-safeguard jurisdiction.

Beyond the question of effectiveness, lack of preemption would frustrate the justifiable objective of a uniform national policy on regulation of biohazards. Scientific research depends upon the ability of scientists to replicate one another's research. With varying standards from locality to locality, this would become extremely difficult, leading researchers to congregate in those localities with the least restrictive regulations. ${ }^{32}$ Furthermore, it is not reasonable

27 Cambridge Resumes Genetic Research, 111 Scr. News 103 (1977).

28 The Cambridge Experimental Review Board, 33 BuLL. Aтом. Scr. 23 (1977).

29 For the responses of other localities, see Wade, Grass-Roots, supra note 7.

30 See Culliton, supra note 4 , at 301 . The Board itself believed federal control to be called for. Cambridge Experimental Review Board, supra note 28.

31 Grad, Legislative Responses to the New Biology, Limits and Possibilities, 15 U.C.L.A. L. REv. 480, 486 (1968).

32 Another problem could occur if, for example, a town were to approve a variety of research projects for its medium-containment facility, based on the supposition that a certain organism possessing a high degree of biological containment is available for use by experimenters, and the federal agency in charge of allocating these microorganisms then adopted a policy of making them available only to high containment facilities. The entire basis on which the local community approved its plan would be eviscerated. As a result, researchers would have to utilize a different organism, not approved by the local agency, or delay or terminate projects for which resources have been allocated.

The unworkability of a federal-state framework is further highlighted by the problems which would be likely to occur if more than one federal agency were to have a role in research regulation. "Cross" preemption results when two or more 
to believe that local regulators would have access to the same quality of information as would exist for a national body. ${ }^{33}$ The area to be regulated is an uncertain and constantly changing one, and the federal government is presumably best equipped to keep abreast of the most recent scientific developments. If localities were to be allowed to regulate individually, a situation could arise in which the local restrictions would be either too restrictive or not restrictive enough for an optimal level of research, because of the time lag in receipt of adequate scientific input. In the latter situation, an unreasonable health risk would be created; in the former, valuable research would be unnecessarily curtailed. For these reasons, scientists tend to strongly favor a broad preemption requirement. ${ }^{34}$ They fear that "a local option would set a dangerous precedent for the regulation of basic research in a manner that might deprive society of substantial future benefits." 35

Despite strong political opposition to broad federal preemption, ${ }^{36}$ many of the bills currently before Congress on the subject of DNA regulation address the question of preemption. Both the House bill proposed by Representative Rogers and the Senate bill proposed by Senator Nelson provide for federal preemption of local regulation. ${ }^{37}$ The House bill, however, makes an exception for local laws which are more stringent than federal requirements and which are "necessary to protect health or the environment." 38 Senator Nelson's bill contains the same provision, but adds that the more stringent local requirement must also be "required by compelling local conditions." 39

While not total preemption, the solution offered by the Rogers and Nelson bills may be acceptable. All local regulations are preempted unless specifically approved by the Secretary of Health, Education, and Welfare. This aspect of the provision has been defended on the ground that " $[\mathrm{w}] \mathrm{ith}$ the Secretary involved, a state

federal agencies have equally strong preemptive powers over state regulation on the same subject. The potential dangers of this type of framework have been well illustrated in the regulation of air pollution. See Guilbert, The Relationship Between State and Federal Regulation of Air Polluting Energy Sources in Oregon, 54 ORE. L. REv. 525 (1975).

33 Id. 530.

34 See Gene Legislation: NAS Urges Caution, 111 ScI. News 293 (1977).

$35 \mathrm{Id}$.

36 Wade, Gene Splicing Preemption Rejected, 196 Scr. 406 (1977) [hereinafter cited as Wade, Preemption].

37 H.R. 11192, 95th Cong., 2d Sess. $\$ 106$ (1978); S. 1217, Amend. No. 754, 95th Cong., 1st Sess. $\$ 484$ (1977).

38 H.R. 11192, 95th Cong., 2d Sess. $\$ 106(\mathrm{~b})(2)$ (1978).

39 S. 1217, Amend. No. 754, 95th Cong., 1st Sess. $\$ 484$ (b)(-2) (1977). 
cannot just go ahead and write a more stringent law on its own." 40 By requiring federal approval and a showing of necessity for the more restrictive local regulation to be permitted, the danger of curtailing valuable experimentation would be minimized.

\section{Constitutional Implications of Researgh Regulation}

A threshold question to be addressed before enacting any regulatory scheme is the constitutionality of such action. ${ }^{41}$ While no case law deals directly with the question of how much, if any, effect the first amendment has on governmental regulation of scientific research, it is nevertheless vital to draft regulations with the first amendment in mind, primarily to avoid potential problems of overbreadth. Regulations directed to the dissemination of knowledge gained from particular research would most likely face closer constitutional scrutiny than would regulations aimed directly at research procedures and the dangers potentially arising from their use. ${ }^{42}$

Scientific research fits uneasily within the traditional confines of first amendment doctrine. Conducting an experiment is clearly not an example of pure speech. Nor does it appear to be a physical manifestation of a nonverbal statement. It is not the typical case of a silent attempt at communication, as there is no obviously expressive content, even in the relatively broad senses typically recognized by the Supreme Court. ${ }^{43}$

40 Wade, Preemption, supra note 36 (comments of an NIH official).

41 This discussion will focus on the first amendment implications of governmental control over biological research. Other challenges to state regulation are possible, however. In the case of governmentally funded research especially, it could be argued that regulation of only one type of potentially dangerous research, such as DNA experimentation, violates the equal protection or due process clause of the fourteenth amendment. For an examination of this claim in a related research context, see Comment, Governmental Control of Research in Positive Eugenics, 7 U. Mrch. J.L. REF. 615, 628-29 (1974). The thrust of the equal protection claim is lessened if, as this Comment advocates, all research presenting a biological hazard is controlled together.

42 Regulation of information dissemination might be attempted in order to avoid potential public hysteria based on popular interpretation of and speculation about the uses of newly discovered knowledge.

43 See, e.g., Thornhill v. Alabama, 310 U.S. 88 (1940) (peaceful picketing assimilated to the general right of free speech. This finding was later cut back when the picketing involved any questions of violence, Milk Wagon Drivers Union v. Meadowmoor Dairies, 312 U.S. 287 (1941), or if the picketing constituted illegal economic coercion under valid state law, Giboney v. Empire Storage \& Ice Co., 336 U.S. 490 (1949)); United States v. O'Brien, 391 U.S. 367 (1968) (destruction of draft card assumed to include an element of expression); Tinker v. Des Moines Independent Community School District, 393 U.S. 503 (1969) (wearing of black armband a symbolic act within meaning of free speech clause); Spence v. Washington, 418 U.S. 405 (1974) (given the context, taping a peace symbol to an American flag was a form of communication and a species of protected expression. Cf. West Virginia State Bd. of Educ. v. Barnette, 319 U.S. 624 (1943) (refusal to salute the 
On the other hand, however, strong arguments for viewing regulation of scientific experimentation as implicating first amendment interests can be made. DNA research is impossible without experimentation; advances in knowledge about uncertain scientific areas generally depend upon research as well as pure thought.44 Because pure thought is not regulable, and regulation cannot therefore be justified based upon the content of what is being thought about, it should not be possible to circumvent this restriction on regulation by removing the means to accomplish an unwanted thought. For this reason, experimentation might qualify for that protection granted to "the process of discovering truth." 45 Thomas Emerson has written that by enacting the first amendment to the Constitution, the founders were providing protection for the fundamental societal interest in truth-seeking. Today, he writes, we conceive of this interest as "advancing knowledge" or "reaching the better decision." 46 According to Emerson, while the first amendment developed in the political realm, the truth-seeking principle has its roots in the scientific method. The process of discovering the political "truth"

operates upon the same principles as those that guided the men of science: the refusal to accept existing authority; the constant search for new knowledge; the insistence upon exposing their facts and opinions to opposition and criticism; the belief that rational discussion produces the better, though not necessarily the final, judgment. ${ }^{47}$

Moreover, even though the concern for factfinding and the "marketplace of ideas" has been traditionally associated with the political system, ${ }^{48}$ there is no reason to place such a limiting scope upon the first amendment. There is evidence that the founders did not intend freedom of expression, which included information exchange, to be limited to politics alone. It has been suggested that the fact that freedom of conscience was protected in the religion clause indicates that "the scope of the constitutional protection was

flag involved free expression); Stromberg v. California, 283 U.S. 359 (1931) (unconstitutional to ban use of red flag, as it is a form of nonverbal political expression).

44 See Smith, Manipulating the Genetic Code: Jurisprudential Conundrums, 64 GEo. L.J. 697, 732 (1970).

45 Emerson, Colonial Intentions and Current Realities of the First Amendment, 125 U. PA. L. Rev. 737, 740 (1977).

46 Id. 741 .

$47 \mathrm{Id}$.

48 See, e.g., Abrams v. United States, 250 U.S. 616, 630 (1919) (Holmes, J., dissenting). Cf. New York Times Co. v. Sullivan, 376 U.S. 254 (1964) (constitution mandates free and robust debate about public officials). 
intended to extend to religion, art, science, and all areas of human learning and knowledge." 48 Justice Douglas has similarly averred that "the State may not, consistently with the spirit of the First Amendment, contract the spectrum of available knowledge." 50 Furthermore, recent cases granting protection to commercial speech ${ }^{51}$ indicate that the present Court will not define the protections of the first amendment so narrowly as to totally exclude the freedom of scientific inquiry..$^{52}$

Another potential source of protection for scientific research is the constitutionally-based concept of academic freedom. In Sweezy v. New Hampshire, ${ }^{53}$ the Supreme Court noted that:

[t]o impose any strait jacket upon the intellectual leaders in our colleges and universities would imperil the future of our Nation. No field of education is so thoroughly comprehended by man that new discoveries cannot yet be made. . . . Scholarship cannot flourish in an atmosphere of suspicion and distrust. Teachers and students must always remain free to inquire, to study and to evaluate, to gain new maturity and understanding; otherwise our civilization will stagnate and die. ${ }^{54}$

The school as a special place for first amendment purposes has been reaffirmed and given support in such later cases as Keyishian $v$.

\section{Emerson, supra note 45 , at 742.}

50 Griswold v. Connecticut, 381 U.S. 479, 482 (1965). See Zemel v. Rusk, 381 U.S. 1, 24 (1965) (Douglas, J., dissenting). "The right to know, to converse with others, to consult with them, to observe social, physical, political and other phenomena abroad as well as at home gives meaning and substance to freedom of expression and freedom of the press." Id. Zemel involved the denial of a passport to travel to Cuba, despite the assertion of a need to search for knowledge. This holding may imply that there are limits, albeit indistinct ones, to the principle of free speech as a search for truth and knowledge. It is unlikely, however, that the scientist would face the same barriers as the petitioners in Zemel, who were feared to have invented a makeshift excuse in order to obtain a passport to an otherwise prohibited country. A scientist researching DNA, claiming that an experiment was necessary to further his knowledge, would be in a much more believable position. Further distinctions between Zemel and the typical biological research situation lie in the traditional governmental interest in foreign policy and national security implicated in Zemel but not necessarily present in the research case.

ธ1 E.g., Virginia State Bd. of Pharmacy v. Virginia Citizens Consumer Council, 426 U.S. 748 (1976).

52 It has also, however, been argued that only expressly political speech and expression are protected by the first amendment. See Bork, Neutral Principles and Some First Amendment Problems, 47 InD. L.J. 1 (1971).

53354 U.S. 234 (1957).

54 Id. 250 (emphasis added). 
Board of Regents, ${ }^{55}$ Whitehill v. Elkins, ${ }^{56}$ and Shelton v. Tucker. ${ }^{57}$ While this doctrine has been slow to develop, it does "give promise that the principles and practices that enable institutions of learning and research to function as social critics and innovators may be entitled to a special place under the protective umbrella afforded by the first amendment." 58

A major difficulty in relying on a doctrine of academic freedom to create protection for scientific experimentation is that the cases in which the doctrine was found were not decided solely on this ground. While the cases say that the academic context makes closer scrutiny of constitutional claims imperative, the decisions would probably have been the same regardless of the academic context, for they all involved an issue of obvious speech infringement either by a loyalty oath requirement or an investigation into subversion. ${ }^{59}$

Another problem of using the academic freedom doctrine to govern the experimentation case is that there the regulation does not so obviously infringe upon speech. In Whitehill, Sweezy, Shelton, and Keyishian, the restraints involved teaching, either directly or indirectly. As teaching primarily involves speech, traditional restraints

55385 U.S. 589 (1967).

Our Nation is deeply committed to safeguarding academic freedom, which is of transcendent value to all of us and not merely to the teachers concerned. That freedom is therefore a special concern of the First Amendment, which does not tolerate laws that cast a pall of orthodoxy over the classroom.

Id. 603.

56389 U.S. 54 (1967).

57364 U.S. 479 (1960). "The vigilant protection of constitutional freedoms is nowhere more vital than in the community of American schools." Id. 487. But see Barenblatt v. United States, 360 U.S. 109 (1959) (teaching fellow cited for contempt for refusing to answer questions about communist party membership. "We think that investigatory power in this domain is not to be denied Congress solely because the field of education is involved." Id. 129.).

58 Emerson, supra note 45, at 746.

59 In Sweezy, New Hampshire sought to question the petitioner about his allegedly subversive activities, including certain lectures he had given at the university. The case turned on the legislature's failure to delegate authority to ask particular questions to the attorney general, who was conducting the investigation on their behalf. The academic freedom principle was said to make it less likely that the legislature sought to inquire into such a highly protected area. Keyishian found a state employment loyalty oath unconstitutionally vague, and also presented a question of dismissal of teachers for communist party membership alone, with no scienter requirement. The vagueness was said to be worse for appearing in an academic setting, but there is no reason to believe that the same oath would not have been equally vague and unconstitutional in another setting. Whitehill was also a loyalty oath case. Shelton involved a state requirement that teachers list the organizations to which they belonged. Even though the state had an interest in regulating its teachers, the scope of the Arkansas statute impinged upon the freedom of association. The fact that teachers were involved was again not determinative. 
on curbing speech have come into play when teaching has been limited. The same result would probably not occur in the case of experimentation regulation, however, because courts would not consider it to be infringement of speech or even expression on an academic freedom theory alone. Consequently, where research is concerned, the academic freedom ideal as a basis for constitutional decisionmaking would exist in something of a first amendment vacuum, dependent on a particular judge's desire or ability to see a relationship between experimentation and first amendment interests.

In addition, it is not clear that academic freedom, even if it did exist as a constitutional test in and of itself, would apply to research only tangentially affiliated with universities or colleges or to commercial research totally outside the academic community. Sweezy, Keyishian, Shelton, and Whitehill were limited on their facts to encroachments on first amendment interests occurring within high schools, colleges or universities. ${ }^{60}$ However, the scope of the quoted language suggests a broader freedom to inquire. Indeed, Justice Douglas has also included "freedom of inquiry, freedom of thought, and freedom to teach," as within the freedom of speech. ${ }^{61}$ Yet, Douglas' position on the breadth of the first amendment is not certain to sway the current members of the Court. ${ }^{62}$

It might also be argued that governmental regulation of scientific experimentation infringes upon some first amendment interest in "personal self-fulfillment." ${ }^{63}$ While it is conceivable that a scientist might claim the right to research as an expression of his "inner self," this claim is not particularly persuasive. As Emerson points out, it would be very difficult in a case of this nature to distinguish protected expression from regulable action. ${ }^{64}$ Biological research is especially inappropriate for protection on this ground. Unlike most of the examples enumerated by Emerson, ${ }^{65}$ the decision to do research is not made within some sphere of privacy; ${ }^{68}$ the research is externally funded and carries both social costs and benefits.

${ }^{60}$ Sweezy and Keyishian involved colleges; Shelton and Whitehill, high schools. 61381 U.S. at 482.

62 For a general discussion of Justice Douglas' views on the first amendment, see Symposium in Honor of Mr. Justice Douglas, 74 Colun. L. Rev. 341 (1974).

63 Emerson, supra note 45 , at 758.

64 Id. 759.

65 Emerson writes that the protection for "personal self-fulfillment" might prohibit "governmental interference with the expression of the individual personality as shown through one's life style-one's clothing, hair style, appearance, mode of living, sexual preferences, career or lack of career." Id. 758.

66 The privacy aspect of the first amendment was articulated by Justice Douglas in Griswold v. Connecticut, 381 U.S. 479 .)(1965). For an examination of an analogous constitutional interest expressed in due process terms, see Hindes, Morality 
On balance, despite the weaknesses of the academic freedom and personal self-fulfillment arguments, it is likely that the courts will be persuaded to afford some first amendment protection to scientific research, perhaps on a truthseeking theory. Assuming this protection exists, governmental regulation would then have to meet the test enunciated in United States $v . O^{\prime}$ Brien, $^{67}$ which held that:

[W] in the same course of conduct, a sufficiently important government interest in regulating the nonspeech element can justify incidental limitations on First Amendment freedoms. . . . [W]e think it clear that a government regulation is sufficiently justified if it is within the constitutional power of the Government; if it furthers an important or substantial governmental interest; if the governmental interest is unrelated to the suppression of free expression; and if the incidental restriction on alleged First Amendment freedoms is no greater than is essential to the furtherance of that interest. ${ }^{68}$

The application of this test to regulation of experimentation occurring in areas of uncertain scientific risk, such as recombinant DNA research, leads to the conclusion that the constitutionality of such regulation will be upheld.

The first requirement of the O'Brien test-that of the constitutional power of the federal government to regulate-is met in the case of biological experimentation by reference to the commerce clause. 69 The case law requires "a close and substantial relationship" between interstate commerce and the business or subject of regulation. ${ }^{70}$ Courts have construed this relationship liberally. ${ }^{71}$ The possible consequences of unregulated recombinant DNA research conducted in any one location on health, agricultural productivity, and the environment nationwide, without regard for state borders, suggest the ready applicability of the commerce clause in this context. ${ }^{72}$

Enforcement Through the Criminal Law and the Modern Doctrine of Substantive Due Process, 126 U. PA. L. REv. 344 (1977).

67391 U.S. 367 (1968).

68 Id. 376-77.

69 U.S. CONST. art. I, $§ 8, \mathrm{cl} .3$.

70 NLRB v. Jones \& Laughlin Steel Corp., 301 U.S. 1 (1937).

71 See, e.g., Heart of Atlanta Motel v. United States, 379 U.S. 241 (1964); Katzenbach v. McClung, 379 U.S. 294 (1964).

72 See Comment, supra note 41 , at 631. See also Balmer, Recombinant DNA: Legal Responses to a New Biohazard, 7 ENvT'L L. 293, 308 (1977). 
The O'Brien requirement of a substantial governmental interest in regulation is also present in the context of a scientific methodology possessing the potential for danger. The interest is substantial to the extent that it could be determined that a particular set of experiments might constitute a danger to human life or health. In Roe v. Wade, ${ }^{73}$ the Supreme Court spoke of a "state's important and legitimate interest" in the health of a mother seeking abortion as well as in the potential life of the child, both of which at a certain point could be sufficiently substantial to outweigh the mother's privacy interest. It is not clear what the necessary quantum of danger or the requisite degree of certainty of danger would have to be in order to outweigh the pursuit of knowledge through experimentation. Yet it is at least worth speculating that courts, unequipped to assess the intricacies of scientific research and regulation, might defer to legislative or administrative judgments about danger in this area.

Given that the motivation for regulation would be to protect the populace and the environment, and assuming that the governmental proscription would be clearly and specifically limited to the regulation of the process of experimentation and not to the underlying search for knowledge, courts could not be expected to find that the governmental interest was related to the suppression of expression. Indeed, this third prong of the O'Brien test is somewhat problematic, as it is unlikely that governments would deliberately design legislation which would run afoul of the first amendment.

The fourth and final requirement of the O'Brien formula is perhaps the most significant for scientists concerned about government regulatory activity. This form of a least restrictive alternative test ${ }^{74}$ holds out the promise that the government will be allowed to regulate only those areas of research where danger to the public can be shown. The difficulty here, once again, is that courts are not competent to decide these issues; given the enormous uncertainty concerning the dangers of DNA research, judges will have no better grasp of the risks involved than will the regulators themselves. Such research regulation also carries an element of policy decisionmaking beyond the function of the judiciary. A small risk of great danger

73410 U.S. 113,162 (1973). While finding a privacy right to procure an abortion, the Court nonetheless permitted some governmental regulation.

74 Shelton v. Tucker also involved a least restrictive alternative analysis. 364 U.S. 479, 487-90 (1960) (citing Lovell v. Griffin, 303 U.S. 444 (1938); Schneider v. State, 308 U.S. 147 (1939); Talley v. California, 362 U.S. 60 (1960)). "Even though the governmental purpose be legitimate and substantial, that purpose cannot be pursued by means that broadly stifle fundamental personal liberties when the end can be more narrowly achieved," 364 U.S. at 488 . 
might well justify regulation as much as would a greater risk of a smaller danger. Thus deference should be given to those best able to make this policy decision. It is likely that the need for regulation will be broadly interpreted. ${ }^{75}$

The foregoing suggests that while scientists may be able to draw support from the first amendment in their desire to protect their research, the degree to which the government will be prevented from regulating experimentation will be limited because of judicial deference to official assessments of danger and official policy judgments as to the balance of risks and benefits of regulation.

The government will be less able constitutionally, however, to curb dissemination of information about the experiments. Because the activity constitutes pure speech and not merely conduct with a speech element, scientists will be able to rely on more restrictive first amendment tests. There will also be less justification for official restraint on such speech. The major justification for regulation of experimentation is that of the potential danger it represents. Merely talking or writing of the experiment does not present the same degree of danger, although it could be argued that the possibility of public fear or hysteria represents such a danger. Such a remote eventuality, however, would be unlikely to succeed as a justification for regulation of pure speech.

Therefore, to justify any restriction on information dissemination, the government would have to show a clear and present danger -an intentional incitement to lawless action. ${ }^{76}$ It is difficult to envision the dissemination of information about a scientific experiment as incitement to commit an illegal act. There would thus appear to be no governmental justification for suppressing speech which disseminates knowledge in this context, and, assuming that courts would apply traditional first amendment tests to scientific speech,

75 Emerson has been extremely critical of $O^{\prime}$ Brien, calling it a "disaster" for its failure to balance. Emerson, supra note 45, at 749-50. He feels that the proper test would be to determine whether the conduct was primarily expressive or action; if expressive it should be granted the full protection of the first amendment. The research concerned with here would constitute action rather than expression, and under Emerson's test, too, would be regulable.

${ }^{76}$ In Brandenburg v. Ohio, 395 U.S. 444 (1969), the Court summarized a large body of free speech law by stating:

These later decisions have fashioned the principle that the constitutional guarantees of free speech and full press do not permit a state to forbid or proscribe advocacy of the use of force or of law violation except where such advocacy is directed to inciting or producing imminent lawless action and is likely to incite or produce such action.

Id. 447. For a discussion of Brandenburg, which involved a Ku Klux Klan rally in Ohio, see Comment, United States v. Kelner: Threats and the First Amendment, 125 U. PA. L. REv. 919, 937 (1977). 
the government would find it nearly impossible to curb this type of expression. In the vast majority of circumstances, DNA researchers can expect to engage unfettered in their professional discourse. The experimental process itself, however, as discussed previously, will undoubtedly face regulation, at least insofar as is deemed necessary to protect the public health and environment. Legislation enacting such regulation must be carefully drawn to avoid potential first amendment challenges.

\section{Methods of Instituting Control}

\section{A. Existing Statutes}

While a number of existing laws can be viewed as enabling the federal government to control biological research, close examination indicates that these statutes alone do not satisfactorily cure the problem. One such statute is the Toxic Substances Control Act (TSCA), ${ }^{77}$ which requires notification of intended uses of potentially dangerous chemical substances, to enable the Environmental Protection Agency (EPA) to regulate their use before any ill effects occur. ${ }^{78}$ Testing occurs if the substance presents an unreasonable environmental or health risk, ${ }^{79}$ or if a previously untested substance is to be produced in mass quantity or exposed to humans. ${ }^{80}$ If as a result of testing danger appears imminent, the EPA must undertake appropriate control procedures through rulemaking. ${ }^{81}$ Emergency procedures may be necessary if rulemaking is not feasible due to time limitations. ${ }^{82}$ The regulatory procedures are triggered when the risk of injury appears imminent, rather than when the harm actually occurs. ${ }^{83}$

The TSCA appears to be a valid means to control dangerous biological research because it provides for testing before any damage is done. ${ }^{84}$ The fact that risk rather than harm is the trigger mechanism allows for regulation at a much earlier stage.

7715 U.S.C. $\$ \$ 2601-2629$ (1976).

78 See Kraus, Environmental Carcinogenesis: Regulation on the Frontiers of Science, 7 ENVT'x L. 83, 115-16 (1976).

7915 U.S.C. $\$ 2603(\mathrm{a})(1)(\mathrm{A})(1976)$.

$80 I d$. $\$ 2603(\mathrm{a})(\mathrm{I})(\mathrm{B})(1976)$.

$81 \mathrm{Id}$. $2603(\mathrm{f})(1976)$.

82 Id. $\$ 2604$ (f)(1) (1976). See Kraus, supra note 78, at 118-19.

$83 \mathrm{Kraus}$, supra note 78 , at 120 .

84 The adverse effects of the lack of regulation of biohazards such as recombinant DNA may occur well after their cause, given that scientific understanding of the subject matter is incomplete and conflicting. By the time they are better understood, they may be dispersed throughout the world. This is analogous in many ways to the problem of environmental carcinogens. See Kraus, supra note 78, at 85. 
The TSGA is not, however, the proper mechanism to control this experimentation. Directed to chemical substances, ${ }^{85}$ the Act would need to be amended to make it applicable to biological agents as well. More importantly, the TSCA is directed to testing of a chemical substance before its commercial production; with recombinant DNA and related topics, the issue is regulation of the basic research, regardless of potential exploitation. The statute fails to address the dangers presented by the research itself, and therefore is an inappropriate vehicle for its regulation.

Also militating against use of the TSCA are its internal problems. The TSCA is a statute of last resort; EPA uses it only when the public interest requires its use because no other law will solve the problem. ${ }^{86}$ This uncertainty would reduce the efficiency with which any useful regulation would be administered.

One of the great shortcomings of the TSCA, making it particularly inappropriate to regulate areas like DNA, is that it gives little guidance as to how its provisions should be applied: "The TSCA clearly calls for a risk-benefit analysis, yet it does not provide direction as to how the various factors should be balanced." 87 While it may not always be appropriate or possible for the legislature to perform the balancing function, ${ }^{88}$ it is at least necessary to provide for some agency or commission particularly suited to interpreting and applying this standard to the research covered. The failure of the TSCA, as presently written, to delegate decisionmaking to a well-qualified body would seem to foreclose the statute's usefulness in this context.

Another federal statute under which regulations directing biological research may possibly be promulgated is the Public Health Services Act (PHSA). ${ }^{89}$ Under the PHSA, the Secretary of Health, Education, and Welfare has the power to create and enforce regulations "as in his judgement are necessary to prevent the introduction, transmission, or spread of communicable diseases [between states or into the country]." 90 "Since one of the major risks of recombinant DNA research is that an organism with unknown properties might be released into the environment and cause an epidemic, regulations

8515 U.S.C. $\$ \$ 2601-2062$ (1976).

${ }^{86} I d . \$ \$ 2605$ (c), 2608(a) \& (b) (1976). See Kraus, supra note 78, at 119. 87 Kraus, supra note 78, at 122 (footnote omitted).

88 See text accompanying notes 106-11 infra.

8942 U.S.C. $\$ \$ 262-264$ (1970). See generally Balmer, supra note 72.

9042 U.S.C. $\$ 264$ (1970). 
to prevent such an occurrence seem to come within the words of the statute." 91

Despite its superficial applicability, the PHSA is ill-equipped to act as a basis for regulation of biological research. While it could be interpreted as allowing for control over the spread of a particular DNA molecule, ${ }^{92}$ because of its language and history it can only arguably be read as sanctioning regulation over particular types and classes of experiments. ${ }^{93}$ Without control over experimentation itself, the ability to curb potential hazards-and therefore the value of the regulation-would be limited.

While the Occupational Safety and Health Act, ${ }^{94}$ (administered by the Occupational Safety and Health Administration (OSHA)), might possibly be used to enforce appropriate safety regulations in the laboratory ${ }^{95}$ since it protects against employee injury by employment-related toxic substances, ${ }^{90}$ two immediate problems arise. First, the Act does not include government employees in its coverage. ${ }^{97}$ Many biological researchers would therefore be unprotected. Second, there is no OSHA coverage over conditions governed by other federal agencies. ${ }^{98}$ Due to the strong possibility that HEW, NIH, EPA, or some other agency may have authority in this area, it is inadvisable to use OSHA to promulgate protective regulations.

Environmental pollution statutes may also present an avenue for control. ${ }^{99}$ The problem with such acts, however, is that they are

91 Balmer, supra note 72, at 310-11.

92 Id. 312 n.97. "[T] disease," and regulations reasonably related to that end would be valid." Id. 312. The broad definition of communicable disease that HEW adopted in connection with the statute would easily encompass recombinant DNA molecules. Id. See 42 C.F.R. $\$ 72.1$ (b) (1976).

93 Balmer, supra note 72, at 312 . "If it could be shown that the likelihood of the spread of disease was [sic] such that the purpose of the statute could be served only by prohibition [of experiments], such rules should be upheld." Id. n.97.

The statute is inappropriate, however, because the dangers of biological research are not confined to the possibility of an epidemic. The PHSA does not address the basic environmental difficulties presented by such research. Another problem is that the risks are uncertain, and a risk-benefit calculation must be performed; the PHSA, however, does not provide for such a balance. Balmer's point is inapposite, for it cannot be shown with the certainty he desires that the spread of disease will be caused by some particular research practice.

0429 U.S.C. $\$ \$ 651-678$ (1970).

95 See Balmer, supra note 72 , at 312 n.99.

9629 U.S.C. $\$ 655$ (b)(5) (1970). See Kraus, supra note 78, at $92 \&$ n.63.

9729 U.S.C. $\$ \$ 652(5) \&(6)(1970)$.

98 Id. $\$ 653(\mathrm{~b})(1)(1970)$.

${ }^{99}$ See Kraus, supra note 78, at 87-88. See, e.g., Clean Air Act, 42 U.S.C. $\$ 1857$ (1970) (definition of hazardous air pollutant as one which "may cause, or contribute to, an increase in mortality or an increase in serious irreversible, or incapacitating reversible, illness." 42 U.S.C. \$1857C-7(a)(1) (1970)); Federal Water Pollution Control Act, 33 U.S.C. $\$ \$ 1251-1376$. (Supp. III 1973). 
geared toward the discharge of hazardous substances in harmful quantities. ${ }^{100}$ As the controversy over the use of recombinants has been in large part fueled by the fact that there is no known safe exposure level to new organisms which the technique may create, such laws provide no real basis for the promulgation of safety regulations in this area.

\section{B. The Role of Congress}

One of the key issues in attempting to regulate potentially hazardous biological research concerns the respective roles to be played by the public and by scientists. Once congressional action is deemed necessary, it must be determined what form such action should take. Should Congress assume responsibility for the basic policy decisions, or should it delegate that responsibility to an administrative agency composed of scientists and laymen?

In the past when Congress has legislated in areas involving considerable factual uncertainty and unclear policy impact, it has tended to give wide scope to administrative agencies' policy judgments. The Nuclear Regulatory Commission, for example, is

[authorized to] establish by rule, regulation, or order, such standards and instructions to govern the possession and use of special nuclear material, source material, and byproduct material as the Commission may deem necessary or desirable to promote the common defense and security or to protect health or to minimize danger to life or property. ${ }^{101}$

Similarly broad, the National Environmental Policy Act of 1969 requires that all federal agencies file a detailed statement of their activities "significantly affecting the quality of the human environment." 102

The various DNA regulation bills in Congress also reflect judgments that significant policymaking in this area should not be done by legislators. The Rogers, Kennedy, and Nelson bills all delegate significant decisionmaking to non-legislative bodies, initially to NIH and eventually to Rogers' and Kennedy's commission ${ }^{103}$ or Nelson's advisory committee. ${ }^{104}$ The Nelson bill, for example, uses language

100 Kraus, supra note 78 , at $87-89$.

10142 U.S.C. $\$ 2201$ (b) (1970).

10242 U.S.C. $\$ 4332(2)(C)$ (1970).

103 H.R. 11192, 95th Cong., 2d Sess. $\$ 201$ (1978); S. 1217, Amend. No. 1713, 95th Cong., 2d Sess. $\$ 201$ (1978).

104 S. 1217, Amend. No. 754, 95th Cong., 1st Sess., $\$ 481$ (1977). 
to the effect that regulations should be issued when "necessary for the protection of health or the environment." 105

Although very much the pattern, this type of delegation should not automatically be assumed. Judge Bazelon has recently pointed out that legislatures in democratic societies "traditionally make the hard value choices. Indeed, this is precisely what [they] are designed to do." 106 Legislative delegation of this task should be viewed with caution, since it is not entirely clear that these value choices cannot be made by Congress in the scientific context. Judge Bazelon points to the attempts by various city councils and state legislatures to regulate DNA research as evidence that "legislatures can become more involved in scientific and technological disputes whenever they wish to do so." 107

On the other hand, however, Congress would have considerable difficulty prescribing explicit standards for regulation of dangerous biological research much beyond what it has attempted in the proposed recombinant DNA legislation. Legislative intervention in other contexts has been considered likely to be inflexible and interfere with efficient government; ${ }^{108}$ congressional activism, particularly in the case of DNA, could be unproductive because of the constantly changing state of knowledge about the subject, its attendant dangers, and the resulting need to constantly reconsider and alter specific proscriptions. ${ }^{109}$ As Judge Bazelon has suggested, "[i]t is not very practical to expect a relative handful of legislators somehow to keep tabs on all the wide-ranging and complex activities in which the government is involved today." 110

One thing the legislature can do is establish the importance with which the basic problem is viewed. While the legislature may not have the time, skills, or rapid information exchange necessary to constantly weigh in timely fashion the risks and benefits of a particular procedure, especially one in a state of flux, it can provide a general evaluation of what it sees as the benefits of the particular research. This is a common feature of the DNA bills. Other than that, in balancing the need for efficient administrative action against the concern for democratically based value judgments, the language

105 Id. $\$ 474(\mathrm{a})(4)$.

106 Bazelon, Coping with Technology Through the Legal Process, 62 ConNen. L. Rev. 817, 829 (1977).

107 Id. 830.

(1976).

108 See generally $\mathrm{K}$. Davis, ADMinistrative Law of taE Seventies, $\$ \$ 200-17$

109 See text accompanying notes 33 \& 34 supra.

110 Bazelon, supra note 106, at 829. 
of regulatory legislation should be left general, and other methods sought to ensure what Bazelon and others have called "interest representation." 111

\section{Creation of a Regulatory Framework}

Proper implementation of new legislation governing control of biologically hazardous experimentation requires a suitable administrative framework which not only encompasses scientists capable of evaluating any technical data involved, but also laymen capable of representing the public at large in the value choices inherent in regulation. ${ }^{112}$ No existing agency, even though it may have been mentioned as a possible regulator of recombinant DNA research, ${ }^{113}$ has the proper "interest representation" 114 to make the difficult value and policy choices necessary for adequate regulation.

In establishing a commission to regulate potentially dangerous experimentation, Congress should consider the composition of other bodies which make policy decisions based on uncertain scientific or technological risks. The Nuclear Regulatory Commission, which develops standards to safeguard the use of nuclear energy, has a membership of five. Two of the commissioners have backgrounds in science and/or technology. ${ }^{115}$ One of the nonscientists has a background in public utility regulation, while the other has had national security planning experience. ${ }^{116}$

Another agency whose membership might act as a guide is the National Commission for the Protection of Human Subjects of Biomedical and Behavioral Research, created in 1974 to study the risks

111 Id.

112 One important consideration in attempting to make a value choice is the ease with which that choice can be made. This, in turn, is a function of the degree to which "benefit" and "risk" can be quantified. For a debate on this issue, see Green, supra note 24; Handler, A Rebuttal: The Need for a Sufficient Scientific Base for Government Regulation, 43 GEo. WASH. L. REv. 808 (1975).

113 The EPA has been mentioned as a possible body to regulate research on recombinant DNA, given its experience in technical rulemaking under various pollution control statutes. See Balmer, supra note 72, at 308-10. The Office of Technology Assessment has also been mentioned because it analyzes scientific issues for congressional committees, although its focus is primarily on the physical rather than the biological sciences. Capron, Reflections on Issues Posed by Recombinant DNA Molecule Technology. III, in ETHICAL AND ScIENTIFic Issues Posed BY Humcan Uses of Molecular Genetics, 265 annals N.Y. Acad. Scr. 71, 74-76 (1976).

114 See text accompanying note 111 supra.

115 The backgrounds of the Commissioners of the Nuclear Regulatory Commission were described by a staff member of the NRC (information on file, U. PA. L. REv.).

116 Id. 
and benefits of research on human subjects ${ }^{117}$ and to make recommendations to the Secretary of HEW for the development of governing guidelines. ${ }^{118}$ Recognizing the need for diverse perspectives, the statute which created the Commission mandated that it be composed of eleven persons from the various fields of "medicine, law, ethics, theology, the biological, physical, behavioral and social sciences, philosophy, humanities, health administration, government, and public affairs." 110

The most recent House bill, ${ }^{120}$ sponsored by Representative Rogers, follows very closely the framework of the National Commission for the Protection of Human Subjects of Biomedical and Behavioral Research. Although basically an interim measure, ${ }^{121}$ the bill does establish a Commission for the Study of Research and Technology Involving Genetic Manipulation. ${ }^{122}$ The thirteen members would be selected by the Secretary of HEW from the fields of "medicine, law, ethics, the biological, physical, and environmental sciences, philosophy, humanities, health administration, government, and public affairs." ${ }^{123}$ The mandate of this Commission would be to study current federal policy towards, and the long-term consequences of, recombinant DNA technology, and make recommendations about the appropriate federal response to such activities. ${ }^{124}$ Senator Kennedy's bill provides for a similar commission consisting of eleven persons, six of whom would be nonbiologists drawn from the categories listed in the Rogers bill, and five of whom would be professional biological researchers. ${ }^{125}$ The bill proposed by Senator Nelson would also provide for some diversity of background, both in the membership of the "Local Biohazard Committee" 126 which would enforce the law, and the "Advisory

117 See Smith, supra note 44, at 721-22. The Commission was created by the National Research Act, Pub. L. No. 93-348, 88 Stat. 342 (1974) (codified in scattered sections of 42 U.S.C. (Supp. IV 1974)).

118 See Smith, supra note 44, at 721-22.

11942 U.S.C. $\$ 218$ (f) (Supp. IV 1974).

120 H.R. 11192, 95th Cong., 2d Sess. (1978).

121 Id. $\$ 102$. Title I of the bill is entitled "Interim Regulation of Recombinant DNA Activities."

122 Id. $\$ 201$.

$123 \mathrm{Id}$. $\$ 201(\mathrm{~b})(1)$.

124 Id. $\$ \S 202,204$ (b).

(1978).

125 S. 1217, Amend. No. 1713, 95th Cong., 2d Sess. $\$ \$ 201(b)(1)$ \& (2)

126 S. 1217, Amend. No. 754, 95th Cong., 1st Sess. $\$ 476(d)(1)(1977)$. 
Committee," which would have the primary responsibility of making recommendations to the Secretary of HEW.127

The use of a mixed body of scientists and laymen is not the only means of assuring that adequate "interest representation" is maintained. Indeed, it may not even be a particularly effective method if it is true, as some have argued, that lay members of such panels give too much weight to the scientists' determinations. ${ }^{128}$ It is also conceivable that over time laymen may tend to sympathize with the scientific point of view and lose their sense of objectivity.

The use of appropriate administrative procedures will be an effective method of ensuring that the decisions made by any regulatory commission set up to guard against biohazards are properly reflective of the interests of both the scientists being regulated and the public at large.

Administrative procedures fall into roughly two categories: rulemaking and adjudication. ${ }^{129}$ Rulemaking has been described as a "quasi-legislative procedure" 130 requiring either the receipt of comments from the public or an oral hearing with a record. ${ }^{131}$ Adjudication is "quasi-judicial" in that it includes trial-type hearings in which an agency enforces specific regulations. ${ }^{132}$ Considering the nature of the issues involved, it is, on balance, more appropriate for the proposed regulatory commission to use rulemaking procedures rather than adjudication. Although scholars are not in agreement as to which procedure is best suited to the promulgation of major policies, ${ }^{133}$ rulemaking seems to be better suited to the resolution of issues growing out of uncertain scientific risks. ${ }^{134}$ Though adjudi-

127 Id. $\$ 481$. The committee would consist of 17 members, one of whom would represent non-professional laboratory employees, one commercial researcher, nine people not concerned with recombinant DNA (at least four of whom would be scientists who could evaluate health risks), one public health expert, one ethicist, and three representatives of the general public. Id.

128 Martin, supra note 24, at 1067.

129 Rulemaking is governed by $\$ 553$ of the Administrative Procedure Act, 5 U.S.C. $\$ 553(1970)$. Adjudication is governed by $\$ 554,5$ U.S.C. $\$ 554$ (1970). 130 Gellhorn, Public Participation in Administrative Proceedings, 81 YALE L.J. 359,369 (1972).

131 Id. 369-70.

132 Id. 371.

133 See, e.g., Shapiro, The Choice of Rulemaking or Adjudication in the Development of Administrative Policy, 78 HARv. L. Rev. 921 (1965).

134 See Williams, "Hybrid Rulemaking" Under the Administrative Procedure Act: A Legal and Empirical Analysis, 42 U. CEI. L. REv. 401, 403-11 (1975); Comment, Implementing the National Environmental Policy Act Through Rulemaking: The Implications of Natural Resources Defense Council, Inc. v. Nuclear Regulatory Commission, 126 U. PA. L. Rev. 148, 161 (1977). 
cation may be a superior method of ascertaining particular facts ${ }^{135}$ it does not supply the more generalized mechanisms needed to resolve value conflicts. ${ }^{136}$ The expensive and time-consuming procedural requirements of adjudication which are designed to ensure accurate proceedings are less significant when the basic issues are, as here, not susceptible to proof. ${ }^{137}$ Rulemaking, on the other hand, has fewer procedural safeguards, but this is because it is less concerned with individual situations; it seeks instead to draw broad conclusions about a large number of episodes. ${ }^{138}$ Rulemaking is preferable to adjudication in this context because it is better suited to extensive public participation ${ }^{139}$ and offers greater flexibility in the decisionmaking process..$^{140}$

The proposed regulatory agency should make use of those types of rulemaking best adapted to public participation. "Rulemaking on a record" 141 is rulemaking in which the agency's decision is based on what transpires at an oral hearing. This type of procedure may involve some problems of public participation, depending on the number of parties directly involved and the nature of the issue.142 "Notice and Comment Rulemaking" allows for greater presentation of public views. The agency proposes tentative rules and seeks comments from interested parties. ${ }^{143}$ One difficulty with this procedure has been in deciding how best to inform the public that changes are being considered and that their comments are desired.144

Given the complexities of regulation of biohazards and the great need for public participation and representation in the basic policy and value choices which must be made, the regulatory body should not be bound by traditional conceptions of rulemaking. Judge Bazelon has pointed to the attempts by Secretary of Transportation William Coleman and NIH Director Donald Fredrickson to involve the public in their respective decisions on the SST and the NIH Guidelines on recombinant DNA research as evidence of open de-

135 It would be for this reason that a regulatory commission would use adjudication in a proceeding such as licensing an installation to do particular research. 130 Williams, supra note 134 , at $407-08$.

137 Id. 407.

138 Id. 406.

139 Cranton, The Why, Where and How of Broadened Public Participation in the Administrative Process, 60 GEo. L.J. 525, 535-36 (1972). See Comment, AEC Rulemaking and Public Participation, 62 GEO. L.J. 1737 (1974).

140 Williams, supra note 134, at 408-09.

141 See 5 U.S.C. $\$ \$ 556 \& 557$ (1970).

142 See Gellhorn, supra note 130 , at 370 .

143 See 5 U.S.C. $\$ 553$.

144 Gellhorn, supra note 130 , at 369 . 
cisionmaking which went beyond the bare minimum of the Administrative Procedure Act, and were sensitive to the value of public participation. ${ }^{145}$ Intensive solicitation of comments from public interest groups and suitable opportunity for their presentation may be the first steps toward greater accountability. ${ }^{146}$

In addition to being innovative in their search for public participation, the commissioners of the new agency may also consider using new techniques to resolve whatever factual issues they may confront. Use of a "science court" to resolve close technical issues regarding the risks of particular procedures may be appropriate. The basic premise of the science court concept is that items of disputed scientific "fact" can be argued by scientists in an adversary proceeding before a panel of scientist-judges. ${ }^{147}$ The "court's"'judgment as to scientific "fact" would then be used by the regulatory body as one piece of evidence in the risk/benefit balance which must be struck. ${ }^{148}$

One benefit of the science court concept is that it creates a division of power between scientists on the one hand and those charged with deciding policy on the other. It allows for finality of scientific judgments, which leads to a better informed policy decision. ${ }^{149}$ The dangers are that the science court's determination may be too rigid, ${ }^{150}$ and that too much importance will be attached to it. ${ }^{151}$

The effectiveness of such a device in the context of biological research is highly questionable. ${ }^{162}$ As Judge Bazelon has pointed out, not all disputes are amenable to the science court process. ${ }^{153}$ When, as with DNA research, the "facts" are likely to remain conjectural and constantly changing, the "court's" judgment will be continuously open to challenge. Some problems are inevitably

145 Bazelon, supra note 106, at 824.

146 Id. See text accompanying notes 17-19, supra. Even though the NIH consulted with several public interest groups, the result remained scientific selfregulation. Similar actions must be taken by a mixed body composed of scientists and those better able to make objective value judgments.

147 Boffey, Experiment Planned to Test Feasibility of a "Science Court," 193 Scr. 129 (1976). See Task Force of the Presidential Advisory Group on Anticipated Advances in Science and Technology, The Science Court Experiment: An Interim Report, 193 Scr. 653 (1976).

148 Boffey, supra note 147.

149 Martin, supra note 24 , at 1064 .

150 Id. 1084-85.

151 Bazelon, supra note 106, at 826-27.

152 See id.; Martin, supra note 24.

153 Bazelon, supra note 106. 
"trans-scientific," 154 requiring policy decisions based on value-laden assumptions which cannot be separated from questions of fact.

Thus a regulatory commission, composed of both scientists and laymen, utilizing, but not limited to, notice and comment rulemaking, with special efforts to gain public participation, is the appropriate administrative mechanism for the regulation of biological research.

\section{CONCLUSION}

Recombinant DNA techniques present a dilemma. On the one hand, they present means of potentially solving problems in cancer research and increasing human knowledge about genetics and inheritance. At the same time, they present an uncertain danger to man's health and environment. Other areas of biological research present similar problems of great potential benefits balanced against uncertain but grave risks. Because of the dangers involved, a regulatory response is mandated, directed not only at recombinant DNA but also at other "biohazards."

A regulatory response to the "biohazard" problem must provide a means of making the basic value choices implicit in any risk/benefit calculus. Scientists, acting alone, are an inappropriate group to perform this balance; they are unable to determine in the name of the public those risks that are worth tolerating.

Because scientists comprise the only group with the technical expertise to ascertain the risks, however, their advice and participation in regulation is essential. For this reason, federal regulation is more appropriate than control at the state or local level; the federal government is better able to keep abreast of the latest scientific advances. Furthermore, federal regulation would avoid the problem of "balkanization" which would result from a piecemeal approach to a problem with potentially wide-ranging consequences.' The federal government should therefore preempt all regulation of biohazards.

In order to avoid successful constitutional challenge, the congressional scheme should be narrowly drawn, regulating only procedures and not dissemination of knowledge. While the scientific community has a possible first amendment interest in not having its research curtailed at all, the government can justify its intrusion as incidental regulation of actions of researchers in the course of protecting the public safety. 
A new statute, specifically directed to the biohazard problem, is needed. Because of the complex nature of the subject matter being regulated, as well as its ever-changing nature, Congress should delegate much of its decisionmaking power to a new regulatory body composed of both scientists and laymen responsive to the public interest. This new agency should utilize those rulemaking procedures which are best suited to maximizing public participation in the decisionmaking process. 